\title{
Istoire de la Chastelaine du Vergier et de Tristan le chevalier. Édition critique établie et présentée par Jean-François Kosta-Théfaine
}

\section{Paola Cifarelli}

\section{(2) OpenEdition}

Journals

\section{Édition électronique}

URL : http://journals.openedition.org/studifrancesi/6558

DOI : ERREUR PDO dans /localdata/www-bin/Core/Core/Db/Db.class.php L.34 : SQLSTATE[HYO00]

[2006] MySQL server has gone away

ISSN : 2427-5856

\section{Éditeur}

Rosenberg \& Sellier

Édition imprimée

Date de publication : 1 septembre 2010

Pagination : 343

ISSN : 0039-2944

\section{Référence électronique}

Paola Cifarelli, « Istoire de la Chastelaine du Vergier et de Tristan le chevalier. Édition critique établie et présentée par Jean-François Kosta-Théfaine », Studi Francesi [En ligne], 161 (LIV | II) | 2010, mis en ligne le 30 novembre 2015, consulté le 08 janvier 2021. URL : http://journals.openedition.org/ studifrancesi/6558; DOI : https://doi.org/10.4000/studifrancesi.6558

Ce document a été généré automatiquement le 8 janvier 2021.

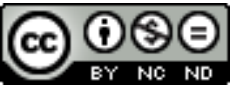

Studi Francesi è distribuita con Licenza Creative Commons Attribuzione - Non commerciale - Non opere derivate 4.0 Internazionale. 


\title{
Istoire de la Chastelaine du Vergier et de Tristan le chevalier. Édition critique établie et présentée par Jean- François Kosta-Théfaine
}

\author{
Paola Cifarelli
}

\section{RÉFÉRENCE}

Istoire de la Chastelaine du Vergier et de Tristan le chevalier. Édition critique établie et présentée par Jean-François KOSTA-THÉFAINE, London, Modern Humanities Research Association, 2009, $112 \mathrm{pp}$.

1 Cette nouvelle édition critique de la mise en prose de La Chastelaine de Vergy élaborée par un auteur anonyme à la fin du $\mathrm{Xv}^{\mathrm{e}}$ siècle vient s'ajouter à celles qu'ont procurées, entre autres, R. Stuip en 1985 et A.M. Babbi la même année. L'introduction est consacrée à la présentation du texte, aux rapports de celui-ci avec son antécédent en octosyllabes $\mathrm{du} \mathrm{XIII}^{\mathrm{e}}$ siècle et à sa fortune; elle contient également une description du manuscrit et des éditions précédentes, des "Remarques sur la langue" et les principes d'édition. L'édition critique est accompagnée de notes codicologiques et explicatives, ainsi que d'un glossaire. Un appendice contient la transcription (intégrale pour deux textes et partielle pour deux autres) de réécritures postérieures, sur lesquelles l'A. annonce une étude en cours d'élaboration.

2 Si l'introduction constitue une synthèse des études menées jusqu'à présent sur ce texte, l'édition critique doit être utilisée avec beaucoup de prudence, à cause des nombreuses coquilles (exellent>excellent, p. 34; doubz>doulx, p. 35; trouver, comfort>trouver comfort, p. 40; et passim), mauvaises lectures (la>sa, p. 41; un brief>en brief, p. 43; vous me le cellés>vous ne le cellés, p. 49; et passim) et incohérences dans la transcription, particulièrement au sujet de qui/qu'i (pp. 46, 52 etc.) et de l'accentuation des mots 
(aprés/après, cf. p. 53). Il en va de même pour l'analyse linguistique, qui mériterait certainement d'être approfondie, aussi bien en ce qui concerne les particularités phonétiques que pour la morphologie, pour laquelle on remarque surtout l'absence d'observations concernant les verbes, qui donnent pourtant lieu à quelques phénomènes dignes d'être signalés (cf., à titre d'exemple, les formes peullent, p. 33, et peureust, p. 53). Le glossaire aussi aurait pu être enrichi par l'introduction de termes du type faire chere (elle onques n'en avoit fait chere ne samblant, p. 36) ou habondance (elle avoit encores sa biaulté vermeille et coulourée pour la grant habondance quy lui avoit esmeü le sanc, pp. 52-53). 